\title{
Socioeconomic Factors and Intimate Partner Violence: A Household Survey
}

\author{
Fernanda Monteiro de Castro Bhona*,1,2 \\ Orcid.org/0000-0003-3263-2929 \\ Carla Ferreira de Paula Gebara ${ }^{3}$ \\ Orcid.org/0000-0003-2725-4687 \\ Ana Regina Noto ${ }^{4}$ \\ Orcid.org/0000-0003-2622-6668 \\ Marcel de Toledo Vieira ${ }^{1}$ \\ Orcid.org/0000-0002-0456-380X \\ Lélio Moura Lourenço ${ }^{1}$ \\ Orcid.org/0000-0003-3664-7335
}

${ }_{1}^{1}$ Universidade Federal de Juiz de Fora, Juiz de Fora, Minas Gerais, Brasil
${ }^{2}$ Tribunal de Justiça de Minas Gerais, Juiz de Fora, Minas Gerais, Brasil
${ }^{3}$ Universidade Católica de Petrópolis, Petrópolis, Rio de Janeiro, Brasil
${ }^{4}$ Universidade Federal de São Paulo, São Paulo, São Paulo, Brasil

\begin{abstract}
This study aimed to describe the prevalence of intimate partner violence in a community sample, as well as identify associations between these behaviors and socioeconomic factors. Given the predominance of these studies in high-income countries, more investigations are needed in low- and middle-income countries. The prevalence of types of intimate partner violence was investigated in a probabilistic sample of 532 women between 18 and 60 years. A sociodemographic questionnaire and The Revised Conflict Tactics Scales (CTS2) were used. Considering recent episodes, the rates of women victimized by their partners were: $48.31 \%, 10.81 \%$ and $7.79 \%$, for psychological, physical and sexual violence, respectively. The rates of these modalities of violence perpetrated by the women were $51.89 \%, 13.73 \%$ and $4.47 \%$, respectively. Logistic regressions indicated that higher educational and socioeconomic levels are associated with a lower likelihood of women being victims or perpetrators of violence. According to the literature, these factors represent nonlinear influences on violence between partners, however, are important for developing intervention strategies for this problem.
\end{abstract}

Keywords: Intimate partner violence, domestic violence, women, socioeconomic factors, socioeconomic status.

* Mailing address: Tribunal de justiça de Minas Gerais, Av. Rio Branco, 2189, $12^{\circ}$ andar, Centro, Juiz de Fora - MG, Brasil 36025-000. Phone: (32) 3239-2691. E-mail: fbhona@gmail.com, carlagebara@gmail.com, anareginanoto@gmail.com, marcel.vieira@ice.ufjf.br and leliomlourenco@gmail.com

Support: Fundação de Amparo à Pesquisa do Estado de São Paulo (FAPESP; processos no2010/510947; e no2010/51837-0); Conselho Nacional de Desenvolvimento Científico e Tecnológico (CNPq; processo n $400675 / 2010-2)$. 


\section{Fatores Socioeconômicos e Violência entre Parceiros Íntimos: Um Levantamento Domiciliar}

\section{Resumo}

O presente trabalho teve o objetivo de descrever a prevalência da violência entre parceiros íntimos em amostra comunitária, bem como identificar associações entre essas condutas e fatores socioeconômicos. Há predominância desses estudos em países de alta renda, sendo necessárias investigações em países de baixa e média renda. Investigou-se prevalências dos tipos de violência entre parceiros íntimos em amostra probabilística de 532 mulheres entre 18 e 60 anos. Foram aplicados: questionário sociodemográfico e Escala de Táticas de Conflito Revisada (CTS2). Abordando episódios recentes, as taxas de vitimização da mulher pelo parceiro foram: 48,31\%, 10,81\% e 7,79\%, para violência psicológica, física e sexual, respectivamente. As taxas de agressão perpetradas pelas mulheres nessas modalidades foram: $51,89 \%$, $13,73 \%$ e 4,47\%, respectivamente. Regressões logísticas indicaram que maiores níveis educacionais e socioeconômicos associam-se a menor probabilidade da mulher praticar e sofrer violência. Segundo a literatura, esses fatores representam influências não lineares na violência entre parceiros, mas são importantes na elaboração de estratégias de intervenção junto ao problema.

Palavras-chave: Violência entre parceiros íntimos, violência doméstica, mulheres, fatores socioeconômicos, status socioeconômico.

\section{Factores Socioeconómicos y Violencia de Pareja: Una Encuesta de Hogares}

\section{Resumen}

Este estudio tuvo como objetivo describir la prevalencia de la violencia de pareja en muestra de la comunidad y la identificación de la asociación entre estos comportamientos y los factores socioeconómicos. Hay un predominio de estos estudios en los países de altos ingresos, y la investigación necesaria en los países de bajos y medianos ingresos. Se investigó la prevalencia de tipos de violencia de pareja en una muestra aleatoria de 532 mujeres de entre 18 y 60 años. Se aplicaron: cuestionario sociodemográfico y Escalas de Tácticas de Conflicto Revisadas (CTS2). Dirigiéndose a los últimos episodios, socio de los índices de victimización de las mujeres eran 48,31\%, 10,81\% y 7,79\%, para psicológica, física y sexual, respectivamente. Las tasas de agresiones perpetradas por las mujeres en estos arreglos fueron $51,89 \%, 13,73 \%$ y $4,47 \%$, respectivamente. Regresiones logísticas indicaron que los mayores niveles educativos y socioeconómicos están asociados con una menor probabilidad de que las mujeres que sufren la violencia y la práctica. Según la literatura, estos factores representan influencias no lineales en la violencia de pareja, pero son importantes en el desarrollo de estrategias de intervención con el problema.

Palabras clave: Violencia de pareja, violencia doméstica, mujeres, factores socioeconómicos, estatus socioeconómico.

"Violence between intimate partners refers to any behavior in an intimate relationship that causes physical, psychological or sexual harm to those involved in this relationship" (Krug, Dahlberg, Mercy, Zwi, \& Lozano, 2002, p. 89). In couple relationships, these behaviors usually express themselves in the following ways: physical (the use of physical force with the intention of causing harm to the other); psychological (covering verbal or gestural aggression, with the intention of humiliating, threatening or damaging the self-esteem, for 
example); sexual (with imposition of sexual practices against the will of the person or that propitiate his/hervictimization; Krug etal., 2002).

The phenomenon encompasses current and past, hetero or homosexuals relationships (Lamoglia \& Minayo, 2009; Morgan et al., 2016). Although studies on the subject initially only dealt with female victimization in couple relationships, in the last years an increase has been observed of investigations considering the behavior of both men and women in these situations, from the recognition that behaviors of violence, including physical, are also adopted by female partners towards male partners, but with varying impacts on the health of men and women (Archer, 2002; Capaldi, Knoble, Shortt, \& Kim, 2012; Dossi, Saliba, Garbin, \& Garbin, 2008; Gebara, 2014; Moore et al., 2008; Straus, 1999).

Another trend in the studies on the subject is the adoption of an approach that considers the multi-causality of situations of violence between couples. Thus, a focus on a developmental perspective, that considers the interaction of factors at different levels, has been useful for comprehending the phenomenon and developing intervention and prevention strategies (CarvalhoBarreto, Bucher-Maluschke, Almeida, \& DeSouza, 2009; Ellsberg \& Heise, 2005; Jewkes, Flood \& Lang, 2015; Krug et al., 2002). Among these factors, the following can be mentioned: individual characteristics such as demographic data of age and education; interpersonal and community contexts, which involve family and peer interactions and influences in different contexts; and influences of broader interactional patterns, of the society and of the culture (Capaldi et al., 2012; Ellsberg \& Heise, 2005; Michau, Horn, Bank, Dutt \& Zimmerman, 2015).

Higher educational and socioeconomic levels have been associated with lower rates of violence between intimate partners, while lower age and family and community history of involvement with violence are related to the greater occurrence of these events in different cultures, according to results from the World Health Organization - WHO (Abramsky et al., 2011). Regarding specific socioeconomic factors, some national studies have investigated these findings, discussing their relevance in comprehending the aggressiveness between couples (Colossi, Razera, Haack, \& Falcke, 2015; D'Oliveira et al., 2009; Schraiber, D'Oliveira, \& França-Júnior, 2008; Zaleski, Pinsky, Laranjeira, Ramisetty-Mikler, \& Caetano, 2010b).

However, different methodologies for collecting and analyzing these socioeconomic data in the different studies undermine the comprehension of the role they play in the occurrence of intimate partner violence. Thus, it can be observed that socioeconomic factors are either used exclusively to describe the samples, or considered as possible protection or risk factors for the events studied, or as possible confounding variables in the identification of associations (Capaldi et al., 2012). In addition, there is a predominance of studies in high-income countries, with research in middle- and lowincome countries being necessary, considering that cultural, economic, political and historical differences give these factors specific outlines (WHO, 2010).

In this sense, some explanatory hypotheses have been discussed in order to comprehend how factors such as levels of income and education contribute to the occurrence of intimate partner violence. According to Jewkes (2002), despite these events occurring in all socioeconomic groups, poverty often leads the couple to conflicts over family finances, with violent behavior possibly erupting at such times. However, the author mentions studies in countries such as Thailand and South Africa that do not confirm this understanding, which suggest that levels of conflict and situations of extreme poverty impact on this relationship.

Also based on research findings, Jewkes (2002) highlighted that absolute levels of income or financial independence of the woman do not necessarily provide protection from violence. A study conducted in Nigeria (Antai, 2011) found that women who had higher incomes than their partners were more likely to suffer physical and sexual violence. Similarly, the financial autonomy of women in a rural region of Brazil represented a risk factor for violence among 
intimate partners in research conducted by D'Oliveira et al. (2009). These findings suggest that economic independence itself does not diminish the chances of victimization, especially if these conditions are contrary to cultural gender norms that advocate male dominance (Abramsky et al., 2011).

According to a WHO publication on educational levels, one of the risk factors for female victimization most consistently identified in studies is low female education (2010). Conversely, a literature review undertaken by Capaldi et al. (2012), which investigated intimate partner violence practiced and suffered by men and women in high-income countries, indicated that education, in general, has some association with the phenomenon. However, this often disappears when controlling for other proximal factors, such as the level of conflict in the relationship. Thus, based on the studies analyzed, they concluded that among the indicators of socioeconomic status, unemployment and low income seem to be more robust predictors than education.

Regarding the association between education and violence, Jewkes (2002) cautioned that it appears to be complex. Although a higher educational level may represent the acquisition of social skills and resources to deal with situations of violence, giving women protection, on the other hand it may also involve them in situations of greater risk for their victimization. This would come from access and adherence to more liberal ideas that would possibly challenge traditional gender roles in which men's dominance over women is observed, especially in societies in which such roles undergo transformations. In the same way as economic disparity over the partner, educational disparity could also pose a risk for greater victimization (WHO, 2010).

In view of these issues, this article aims to describe the prevalence of intimate partner violence in a sample composed of women living in two locations with distinct income profiles in the city of Juiz de Fora/MG. In addition, it intends to identify associations between these conducts and socioeconomic factors in the sample.

\section{Method}

\section{Participants}

The study included 532 women who had a partner, 291 of whom lived in a neighborhood with lower socioeconomic status and 241 in a neighborhood with higher income. Participants aged $31-40$ years $(31.53 \%)$, with a high school education (30.13\%), belonging to class C (46.28\%) and performing some type of professional activity (56.98\%) predominated, as presented in Table 1.

\section{Instruments}

Two instruments were used: a sociodemographic questionnaire, specifically developed for the study, and the Revised Conflict Tactics Scales, adapted from the Revised Conflict Tactics Scales - CTS2 (Moraes, Hasselmann, \& Reichencheim, 2002). The sociodemographic questionnaire was composed of multiple choice questions that addressed: age, work situation and education of the woman and the partner, as well as possession of items. The latter information was used for the socioeconomic characterization of the participants according to the Brazilian Economic Classification Criterion (CCEB) of the Brazilian Association of Market Research Companies (ABEP, 2009). This criterion estimates the individual income, according to economic classes (A1, A2, B1, B2, C1, C2, $\mathrm{D}, \mathrm{E})$ through the score attributed to an index composed of: ownership of items and education of the head of the family.

The Revised Conflict Tactics Scales (CTS2) presents seventy-eight questions, which address the occurrence of behaviors that may have been practiced by the respondent or his/ her partner. It includes actions of: negotiation, physical violence, psychological aggression, consequences of the violence on health (injury) and sexual coercion between the couple. Physical violence is contemplated with items such as: throwing something at the other that could lead to injury; twisting the arm or pulling the hair; pushing; using a knife or gun against the partner; 
Table 1

Sociodemographic Characterization of the 532 Participants

\begin{tabular}{lcc}
\hline Characteristic & $N$ & $\%$ \\
\hline Age & 108 & \\
18 to 30 years & 163 & 18.58 \\
31 to 40 years & 140 & 31.53 \\
41 to 50 years & 121 & 25.75 \\
51 to 60 years & & 24.14 \\
Education & 178 & \\
Incomplete elementary education & 94 & 28.97 \\
Complete elementary/incomplete high school & 166 & 15.14 \\
Complete high school & 93 & 30.13 \\
Incomplete/complete higher education & & 25.76 \\
Economic class & 60 & \\
D / E & 287 & 4.67 \\
C1 / C2 & 182 & 46.28 \\
A1 /A2 / B1 / B2 & & 44.05 \\
Occupation & 224 & \\
Did not work & 308 & 43.02 \\
Worked & & 56.98 \\
Neighborhood & 291 & \\
Lower purchasing power & 241 & \\
Higher purchasing power & & \\
\hline
\end{tabular}

Note. The absolute frequencies $(n)$ reflect the sample sizes in the categories presented in the table. The proportions (\%) were estimated considering the sample weights.

choking or strangling; spanking. Psychological aggression is characterized by actions such as: insulting or swearing at the partner; calling the partner fat, ugly or something similar; destroying something of theirs on purpose; screaming or shouting at the partner; threatening to hit or throw something at the other. The health consequences, classified as injury, address situations in which one of the members of the couple: received a twist, bruise, "purple mark" or small cut because of a fight; passed out due to being hit on the head during a fight; went or should have gone to a doctor or health service because of a fight; or broke a bone because of a fight. Sexual coercion includes some of the following: forcing a partner to have sex without using a condom; using force such as holding or hitting the partner or using a weapon to force him/her to perform oral or anal sex; or insisting on having sex with the partner, against the will of the partner, without using physical force (Moraes et al., 2002).

The CTS2 has been the subject of studies for its validation in the national context, with reliability estimates (kappa) above 0.75 , and internal consistency between $0.65-0.86$ (Moraes \& Reichencheim, 2002). As foreseen in the original instrument (Straus, Hamby, Boney-McCoy, \& Sugarman, 1996), the temporal period investigated was adapted, addressing the violence practiced/suffered in the previous three months 
to meet broader research objectives, in which the present study was included (Gebara, 2014).

\section{Data Collection Procedures}

Data collection began in May 2011 and was completed in August 2012. The women were approached in their respective homes by trained researchers, these being undergraduate Psychology students. The sociodemographic questionnaire was applied as an interview and the CTS2 was filled out directly by the participants in order to guarantee their privacy, given the delicate nature of the issues addressed.

A household survey was conducted by probabilistic sampling in two neighborhoods of the city of Juiz de Fora /MG, to identify women between 18 and 60 years of age who maintained affective relationships and cohabited with their partners. The drawing of two neighborhoods with different income profiles was carried out in order to include diverse socioeconomic levels. In order to not include situations of extreme poverty or wealth, the locations between the $20^{\text {th }}$ and $30^{\text {th }}$ percentiles and between the $70^{\text {th }}$ and $80^{\text {th }}$ percentiles of income were considered, according to data from the Demographic Census of the Brazilian Institute of Geography and Statistics (IBGE), carried out in 2000.

In each neighborhood, the method of sampling by conglomerates in two stages was chosen: the streets were selected by means of simple random sampling without replacement, and the households were selected by systematic sampling. In each residence drawn, the field researchers addressed all the women who met the inclusion criteria (i.e.: age between 18 and 60 years, having a partner with whom they lived, being literate, and presenting no evident cognitive impairment). The sample calculation considered 3\% maximum error desired for the study, 95\% confidence level, correction for finite populations, sample plan effect equal to 2 , and losses due to refusal of approximately $25 \%$. Further information about the research protocol can be found in a previous publication (Gebara et al., 2015).

\section{Data Analysis Procedures}

The collected data were entered into the STATA (version 11) statistical software and analyzed considering the sample design adopted. The responses obtained in the violence scale were coded and analyzed in the form of categorical variables, considering each subscale. The relevant responses to negotiation behaviors were not analyzed in this study, as they did not meet the objectives of the proposed inquiry. Prevalence data were considered when the respondent admitted the occurrence of at least one of the types of violence investigated during the three months prior to the study. All proportions were weighted considering the sample weights.

Logistic regressions were performed to determine the effects of the socioeconomic factors on intimate partner violence behaviors. The regression was performed for each variable, separately (bivariate analyzes), and also in the model containing all the variables together (adjusted model).

\section{Ethical Procedures}

The project of this study was previously approved by the Research Ethics Committee of the Universidade Federal de Juiz de Fora (UFJF) under the number 481.956. The data were collected after the presentation of the study and signing of the consent form by the participants. For ethical reasons, all the women received, at the end, a leaflet containing information about psychosocial care services aimed at the care of victims of domestic violence in operation in the region.

\section{Results}

Table 2 presents the prevalence of violent behaviors among intimate partners in the previous three months, according to the research participants. Psychological violence presented the highest rates (female victims $48.31 \%$ and aggressors $51.89 \%$ ), followed by physical violence (female victims $10.81 \%$ and aggressors $13.73 \%$ ) and sexual coercion (female victims 
Table 2

Prevalence of Types of Violence in Women in the Previous Three Months

\begin{tabular}{lcc}
\hline & $N$ & $\%$ \\
\hline Physical violence & 78 & \\
$\quad$ Aggressor & 65 & 13.73 \\
$\quad$ Victim & & 10.81 \\
Psychological violence & 281 & \\
$\quad$ Aggressor & 264 & 51.89 \\
Victim & & 48.31 \\
Injury & 26 & \\
$\quad$ Aggressor & 31 & 4.54 \\
$\quad$ Victim & & 4.67 \\
Sexual coercion & 32 & 4.47 \\
Aggressor & 42 & 7.79 \\
$\quad$ Victim & & \\
\hline
\end{tabular}

Note. The absolute frequencies $(n)$ reflect the sample sizes in the categories presented in the table. The proportions $(\%)$ were estimated considering the sample weights.

$7.79 \%$ and aggressors $4.47 \%$ ). The most serious physical violence, represented by acts of injury, affected $4.67 \%$ of the women as victims and $4.54 \%$ of them as aggressors of the partners.

As can be seen, the study participants stated that they had practiced more physical and psychological violence behaviors than they had suffered from their partners. With regard to the most serious physical violence (injury) and sexual violence, this situation was reversed, with the partners adopting these behaviors more frequently.

In the adjusted model, presented in Table 3 , logistic regressions indicated an association between a higher level of education of the women and more severe physical aggression (injury) practiced by the women. This indicates that women with higher levels of education presented less chance (OR: 0.04 and CI: 0.000.43 ) of practicing more severe physical violence against their partners when compared to those who had incomplete elementary education.

Also as indicated in Table 3, associations were found between socioeconomic status and sexual and psychological violence between partners. Women in the $\mathrm{A} / \mathrm{B}$ and $\mathrm{C}$ classes presented less chance (OR: 0.13 CI:0.02-0.69 and OR: 0.22 CI: $0.06-0.78$ respectively) of suffering sexual violence practiced by the partner when compared to those in the $\mathrm{D} / \mathrm{E}$ classes. In addition, the women who lived in the neighborhood with higher purchasing power had less chance (OR: 0.14 and CI:0.03-0.64) of practicing sexual violence against their partners, when compared to those living in the location with the lower socioeconomic status. Regarding psychological violence, the adjusted analyses indicated that residing in a neighborhood with greater purchasing power represented a lower chance of being a victim (OR:0.47 and CI:0.300.73 ) or aggressor (OR:0.45 and CI:0.28-0.72) of the partner.

The work situation of the women, as well as their age, did not present statistically significant associations with the behaviors of violence between intimate partners investigated. This included both receiving and perpetrating these acts by the respondents. 
Table 3

Associations between Socioeconomic Variables and Intimate Partner Violence

\begin{tabular}{|c|c|c|c|c|c|c|c|c|}
\hline \multirow[t]{3}{*}{ Violence } & \multicolumn{2}{|c|}{ Physical } & \multicolumn{2}{|c|}{ Psychological } & \multicolumn{2}{|c|}{ Injury } & \multicolumn{2}{|c|}{ Sexual coercion } \\
\hline & Aggressor & Victim & Aggressor & Victim & Aggressor & Victim & Aggressor & Victim \\
\hline & $\begin{array}{c}\text { OR } \\
\text { CI } 95 \%\end{array}$ & $\begin{array}{c}\text { OR } \\
\text { CI } 95 \%\end{array}$ & $\begin{array}{c}\text { OR } \\
\text { CI } 95 \%\end{array}$ & $\begin{array}{c}\text { OR } \\
\text { CI } 95 \%\end{array}$ & $\begin{array}{c}\text { OR } \\
\text { CI } 95 \%\end{array}$ & $\begin{array}{c}\text { OR } \\
\text { CI } 95 \%\end{array}$ & $\begin{array}{c}\text { OR } \\
\text { CI } 95 \%\end{array}$ & $\begin{array}{c}\text { OR } \\
\text { CI } 95 \%\end{array}$ \\
\hline Age & $\begin{array}{c}0.97 \\
{[0.94-1.01]}\end{array}$ & $\begin{array}{c}0.97 \\
{[0.94-1.00]}\end{array}$ & $\begin{array}{c}0.98 \\
{[0.96-1.00]}\end{array}$ & $\begin{array}{c}1.00 \\
{[0.97-1.02]}\end{array}$ & $\begin{array}{c}0.98 \\
{[0.93-1.02]}\end{array}$ & $\begin{array}{c}0.99 \\
{[0.94-1.05]}\end{array}$ & $\begin{array}{c}0.98 \\
{[0.94-1.02]}\end{array}$ & $\begin{array}{c}1.02 \\
{[0.98-1.07]}\end{array}$ \\
\hline \multicolumn{9}{|l|}{ Education } \\
\hline $\begin{array}{l}\text { Incomplete } \\
\text { elementary }\end{array}$ & 1.00 & 1.00 & 1.00 & 1.00 & 1.00 & 1.00 & 1.00 & 1.00 \\
\hline $\begin{array}{l}\text { Complete } \\
\text { elementary/ } \\
\text { incomplete } \\
\text { high school }\end{array}$ & $\begin{array}{c}0.82 \\
{[0.33-2.05]}\end{array}$ & $\begin{array}{c}1.40 \\
{[0.54-3.60]}\end{array}$ & $\begin{array}{c}1.03 \\
{[0.58-1.81]}\end{array}$ & $\begin{array}{c}0.99 \\
{[0.44-2.25]}\end{array}$ & $\begin{array}{c}0.83 \\
{[0.14-4.96]}\end{array}$ & $\begin{array}{c}1.52 \\
{[0.43-5.40]}\end{array}$ & $\begin{array}{c}0.61 \\
{[0.15-2.45]}\end{array}$ & $\begin{array}{c}1.67 \\
{[0.40-6.89]}\end{array}$ \\
\hline $\begin{array}{l}\text { Complete } \\
\text { high school }\end{array}$ & $\begin{array}{c}1.34 \\
{[0.61-2.91]}\end{array}$ & $\begin{array}{c}1.58 \\
{[0.64-3.90]}\end{array}$ & $\begin{array}{c}1.70 \\
{[0.95-3.05]}\end{array}$ & $\begin{array}{c}1.18 \\
{[0.65-2.14]}\end{array}$ & $\begin{array}{c}0.78 \\
{[0.19-3.09]}\end{array}$ & $\begin{array}{c}0.83 \\
{[0.24-2.87]}\end{array}$ & $\begin{array}{c}0.80 \\
{[0.23-2.73]}\end{array}$ & $\begin{array}{c}2.64 \\
{[0.89-7.78]}\end{array}$ \\
\hline $\begin{array}{l}\text { Incomplete/ } \\
\text { complete } \\
\text { higher } \\
\text { education }\end{array}$ & $\begin{array}{c}0.28 \\
{[0.06-1.28]}\end{array}$ & $\begin{array}{c}0.72 \\
{[0.15-3.33]}\end{array}$ & $\begin{array}{c}1.01 \\
{[0.50-2.03]}\end{array}$ & $\begin{array}{c}1.17 \\
{[0.55-2.52]}\end{array}$ & $\begin{array}{c}0.04 \\
{[0.00-0.43]}\end{array}$ & $\begin{array}{c}0.36 \\
{[0.02-5.26]}\end{array}$ & $\begin{array}{c}1.59 \\
{[0.12-20.59]}\end{array}$ & $\begin{array}{c}4.86 \\
{[1.54-15.35]}\end{array}$ \\
\hline \multicolumn{9}{|l|}{$\begin{array}{l}\text { Economic } \\
\text { Class }\end{array}$} \\
\hline $\mathrm{D} / \mathrm{E}$ & 1.00 & 1.00 & 1.00 & 1.00 & 1.00 & 1.00 & 1.00 & 1.00 \\
\hline $\mathrm{C} 1 / \mathrm{C} 2$ & $\begin{array}{c}0.54 \\
{[0.22-1.31]}\end{array}$ & $\begin{array}{c}0.65 \\
{[0.23-1.81]}\end{array}$ & $\begin{array}{c}0.86 \\
{[0.42-1.77]}\end{array}$ & $\begin{array}{c}1.02 \\
{[0.50-2.07]}\end{array}$ & $\begin{array}{c}0.90 \\
{[0.23-3.50]}\end{array}$ & $\begin{array}{c}0.96 \\
{[0.38-2.41]}\end{array}$ & $\begin{array}{c}0.48 \\
{[0.11-1.99]}\end{array}$ & $\begin{array}{c}0.22 \\
{[0.06-0.78]}\end{array}$ \\
\hline $\begin{array}{l}\mathrm{A} 1 / \mathrm{A} 2 / \mathrm{B} 1 \\
/ \mathrm{B} 2\end{array}$ & $\begin{array}{c}0.66 \\
{[0.32-1.38]}\end{array}$ & $\begin{array}{c}0.69 \\
{[0.25-1.87]}\end{array}$ & $\begin{array}{c}0.62 \\
{[0.28-1.34]}\end{array}$ & $\begin{array}{c}0.65 \\
{[0.31-1.37]}\end{array}$ & $\begin{array}{c}1.43 \\
{[0.32-6.21]}\end{array}$ & $\begin{array}{c}0.75 \\
{[0.18-3.05]}\end{array}$ & $\begin{array}{c}0.29 \\
{[0.04-1.87]}\end{array}$ & $\begin{array}{c}0.13 \\
{[0.02-0.69]}\end{array}$ \\
\hline \multicolumn{9}{|l|}{ Occupation } \\
\hline Did not work & 1.00 & 1.00 & 1.00 & 1.00 & 1.00 & 1.00 & 1.00 & 1.00 \\
\hline Worked & $\begin{array}{c}0.61 \\
{[0.34-1.11]}\end{array}$ & $\begin{array}{c}0.83 \\
{[0.38-1.81]}\end{array}$ & $\begin{array}{c}0.75 \\
{[0.51-1.11]}\end{array}$ & $\begin{array}{c}0.89 \\
{[0.60-1.33]}\end{array}$ & $\begin{array}{c}0.47 \\
{[0.20-1.10]}\end{array}$ & $\begin{array}{c}0.69 \\
{[0.29-1.62]}\end{array}$ & $\begin{array}{c}0.94 \\
{[0.43-2.04]}\end{array}$ & $\begin{array}{c}0.63 \\
{[0.36-1.10]}\end{array}$ \\
\hline \multicolumn{9}{|l|}{ Neighborhood } \\
\hline $\begin{array}{l}\text { Lower } \\
\text { purchasing } \\
\text { power }\end{array}$ & 1.00 & 1.00 & 1.00 & 1.00 & 1.00 & 1.00 & 1.00 & 1.00 \\
\hline $\begin{array}{l}\text { Higher } \\
\text { purchasing } \\
\text { power }\end{array}$ & $\begin{array}{c}0.62 \\
{[0.31-1.26]}\end{array}$ & $\begin{array}{c}0.57 \\
{[0.26-1.22]}\end{array}$ & $\begin{array}{c}0.45 \\
{[0.28-0.72]}\end{array}$ & $\begin{array}{c}0.47 \\
{[0.30-0.73]}\end{array}$ & $\begin{array}{c}1.28 \\
{[0.38-4.28]}\end{array}$ & $\begin{array}{c}0.66 \\
{[0.24-1.82]}\end{array}$ & $\begin{array}{c}0.14 \\
{[0.03-0.64]}\end{array}$ & $\begin{array}{c}0.67 \\
{[0.23-1.90]}\end{array}$ \\
\hline
\end{tabular}

Note OR = Odds Ratio; $\mathrm{CI}=$ Confidence Interval. 


\section{Discussion}

The present study showed the prevalences of types of intimate partner violence in a probabilistic sample of women and their associations with socioeconomic factors. These have been highlighted in the literature as important aspects to be considered in the elaboration of prevention and intervention strategies (Capaldi et al., 2012; WHO, 2010) to deal with this problem. In addition, the study was conducted with methodological rigor, which is important to characterize the phenomenon. The locations studied acquire relevance as they reflect distinct socioeconomic characteristics, in a country marked by social inequalities, as is the case of Brazil, which presents a different profile to the high-income countries, where this type of study is usually carried out.

The prevalences found, although they depict two different neighborhoods of a city in the country, are in part similar to those found in other national studies (Reichencheim et al., 2006; Zaleski, Pinsky, Laranjeira, Ramisetty-Mikler, \& Caetano, 2010a) and/or regional studies (GarciaMoreno, Jansen, Hellsberg, Heise, \& Watts, 2006; Moura, Gandolfi, Vasconcelos, \& Pratesi, 2009), considering that the data from this study was restricted to recent episodes (previous three months). The associations of socioeconomic factors with intimate partner violence indicated that higher educational and socioeconomic levels (represented by the neighborhood where the participants lived, level of education and social class) are related to the lower probability of the woman perpetrating episodes, as well as being the victim of physical, psychological and sexual violence.

With regard to the prevalence of psychological violence in this study, the victimization of the woman by the partner was $48.31 \%$, with $51.89 \%$ of the interviewees admitting the perpetration of acts of this nature. A study conducted in two primary healthcare services in the city of São Paulo, Brazil, which interviewed men, found a similar index, with $40 \%$ of victimization of the partners with this type of violence in their lifetime. A study carried out in sixteen national capitals showed higher rates, with a global prevalence of psychological violence practiced by either partner of $78.3 \%$ in the previous year (Reichencheim et al., 2006).

Regarding physical violence, the most evident form of violent behavior, the percentage of this type of recent conduct practiced against women by their partners in this study was $10.81 \%$, emphasizing that it represents two urban populations with different income profiles. Another study carried out in two distinct locations of Brazil (a city representative of a large urban center, and another region composed of rural towns in the northeast) obtained data convergent with that of the present investigation $(8.3 \%$ in the urban area and $12.9 \%$ in the rural area; D'Oliveira et al., 2009; Garcia-Moreno et al., 2006). A study performed by Moura et al. (2009) in a low socioeconomic neighborhood of another Brazilian state capital found physical victimization of women by the partner of $32 \%$ in the previous year, which indicates that the phenomenon presents local variations in its magnitude. Another study of this type of violence, practiced by any of the partners in the previous year, found rates of less serious physical abuse of $21.5 \%$, and of severe physical abuse of $12.9 \%$ (Reichencheim et al., 2006).

The recent victimization of the woman through sexual coercion by the partner in the present study affected $7.79 \%$ of the interviewees, an intermediate value when compared to two regional studies conducted in Brazil. Garcia-Moreno et al. (2006) obtained a prevalence of sexual violence against partners in the previous year of $2.8 \%$ in an urban region and $5.6 \%$ in a rural region. A study carried out in an economically vulnerable area in Brasília (Moura et al., 2009) found rates of sexual victimization of women by the partner in the same period of $15.50 \%$, also indicating local variations in the presence of the phenomenon. One study using a representative sample of the Brazilian urban population, considering the victimization of men and women in their lifetimes, found an overall prevalence of sexual violence practiced by the partner of $8.6 \%$ (Schraiber et al., 2008). 
With regard to the prevalence of injury, which reflects physical violence evidenced through bodily injuries, the data found in this study of female perpetration and victimization (4.54\% and $4.67 \%$, respectively) are similar. According to Oliveira et al. (2009), a representative sample of men and women in the city of São Paulo found that $25.5 \%$ of the women had to seek medical help because of fights with the partner, with only $3.8 \%$ of the male victims presenting this need. The methodological differences between the studies should be mentioned here, as well as what the literature on gender differences says about the evaluation, disclosure and impact of violence behaviors between partners (Lamoglia \& Minayo, 2009; Thompson \& Kingree, 2006).

The finding of the present study that women practice more physical violence than they suffer from their partners converges with data from a study performed in a representative sample of the Brazilian population (Zaleski et al., 2010a). Despite investigating less behaviors of physical violence, this study interviewed men and women about the violence practiced and suffered in the previous year. The female perpetration of physical violence towards the partner in equal or slightly higher proportions than was the case for women was also observed in literature review studies (Archer, 2002; Capaldi et al., 2012). One possible interpretation of these data is that women may underestimate their own acts of violence less than men because they consider these behaviors to be less harmful (Archer, 2002).

In addition, it is important to note that there are differences in the level of severity and impact of these behaviors adopted by men and women (Johnson, Leone, \& Xu, 2014) and in the power exercised by each of them in the relationships (Emery, 2011). There are also differences between an aggressive act, which involves an attack, and situations of abuse, which lead to substantial fear and subjugation (Straus \& Gozjolko, 2014). It can be observed that the consequences of these acts adopted by the couple that are more harmful for the health usually affect women (Straus, 2011).
Contrary to the case of physical violence, sexual violence was the modality in which the woman tended to be more victimized by the partner than the opposite, which was also verified by Zaleski et al. (2010a). Another national study that more broadly considered sexual victimization by the partner for both men and women, at least once in their lifetime, indicated that women tend to be 2.2 times more likely to be victims than men considering this form of violence (Schraiber et al., 2008). In the study mentioned, it was highlighted that the theories of gender relations indicate the behavior of sexual violence as mainly male, however, findings indicated that, although to a lesser degree, they are also behaviors adopted by women, with factors that indicate underreporting by the male victims.

By verifying the associations between socioeconomic factors and intimate partner violence, it was observed that women with a higher level of education were less likely to commit more severe physical violence against their partners. A national and multicultural study indicated this association between education and violence between partners, with higher risks associated with lower educational levels (Abramsky et al., 2011; Reichencheim et al., 2006). A synthesis by Jewkes (2002) and the WHO (2010), indicated that better education levels empower women through networks of relationship, self-confidence and skills in the use of information and resources of society, constituting protection against violent events.

Regarding sexual violence, according to the associations found, women in the $\mathrm{A} / \mathrm{B}$ and $\mathrm{C}$ social classes presented lower chances of suffering this type of partner violence when compared to those belonging to the less favored classes $(D / E)$, which converges with finding of national study that found higher prevalences in populations of lower income (Schraiber et al., 2008). A multicultural study conducted in several countries found that sexual violence practiced by the intimate partner throughout the lifetime varies between locations, ranging from $6 \%$ to $59 \%$ (Garcia-Moreno et al., 2006). According to Jewkes (2002), there is still no clarity about the 
mechanisms that associate sexual violence with unfavorable economic situations, however, one hypothesis is that the need for work and survival can often expose women to situations of vulnerability and disrespect, by strangers and also by the intimate partners.

Another association found from logistic regressions indicates that psychological violence is less likely to happen, considering the woman both in the role of victim and aggressor, in a neighborhood with higher purchasing power. Although this type of violence is considered in the definition of violence by intimate partners (Krug et al., 2002; Schraiber, D'Oliveira, \& Couto, 2006), as well as in the identification of the phenomenon (Garcia-Moreno et al., 2006; Moura et al., 2009; Reichencheim et al., 2006; Schraiber, Barros, Couto, Figueiredo, \& Albuquerque, 2012; Schraiber et al., 2007), several studies that considered the factors associated with these behaviors (Abramsky et al., 2011; Capaldi et al., 2012; Jewkes, 2002) did not use it in the delimitation of behaviors of violence studied, giving priority to the physical and sexual modalities.

However, in several studies psychological violence in the context of couple relationships presents, as in the present investigation, the higher prevalences when compared to other violence in contexts of conjugality (Moura et al., 2009; Reichencheim et al., 2006; Schraiber et al., 2012; Schraiber et al., 2007). In addition, this type of violence is relevant because of its association with other forms of violence (Schraiber et al., 2007), and also because it increases the probability of physical violence occurring (Antai, 2011; Garcia-Moreno et al., 2006). Thus, considering its overlap with other forms of intimate partner violence, the hypothesis can be considered of other studies, which include only physical and sexual violence, in the sense that better socioeconomic conditions probably reflect better living conditions and less stress related to financial issues, thus reducing the occurrence of conflicts and violent behaviors (Capaldi et al., 2012; Jewkes, 2002).

In this investigation, the work situation of the women was not associated with partner violence, a different result from that of a review study conducted by Capaldi et al. (2012) in high-income countries, which indicated higher rates of violence related to unemployment. An explanatory hypothesis for this may be that the fact that working, in the study sample, did not necessarily reflect the economic independence of the woman and/or her empowerment. Accordingly, a national study found that work represented a risk for violence by intimate partners in the country's rural region (D'Oliveira et al., 2009). Another Brazilian study, with a representative sample of the country, specifically addressing sexual violence between intimate partners, found that only the work status of the women and not the men was associated with their victimization by the partner (Schraiber et al., 2008). The study discussed the complexity of the relationship between work and victimization, demonstrating high rates of sexual violence in some segments of workers.

Regarding age, in the present study there was also no association with intimate partner violence, as was found by D'Oliveira et al. (2009) in a rural region of the country. However, broader studies relate lower ages with higher prevalences of the problem (Capaldi et al., 2012; Reichencheim et al., 2006; Zaleski et al., 2010b), which may refer to the hypothesis that recourse to violence would reflect a degree of immaturity in conflict resolution.

It should be emphasized that the sample composed exclusively of women, as well as the approach of a topic with disclosure difficulties are limitations observed in the present study. As implications of the results found, it should be mentioned that, considering that the prevalences found refer to episodes of violence between partners in the previous three months, it is possible to infer that such events are part of the daily life of a significant part of the respondents of this study. Such a finding in itself indicates the relevance of the theme and the need for these events to be the target of intervention and prevention policies in community contexts.

In addition, the finding that both men and women victimize their partners suggests that violence has been a resource used in couple 
relationships, favoring its perpetuation in the contexts of families and communities and contributing to it being a learned model in the social context. These behaviors seem to reflect cultural norms of validation of violence, regardless of gender. Finally, the association between lower chances of occurrence of violent behavior with socioeconomic factors indicates the need for this to be considered in the design of intervention/prevention programs, so that they are adapted to local contexts, without however being taken as linear influences in the situations of violence.

\section{Authors' Contributions}

Substantial contribution in the concept and design of the study: Ana Regina Noto, Carla Ferreira de Paula Gebara, Lélio Moura Lourenço and Marcel de Toledo Vieira.

Contribution to data collection: Carla Ferreira de Paula Gebara, Fernanda Monteiro de Castro Bhona and Marcel Toledo Vieira.

Contribution to data analysis and interpretation: Marcel Toledo Vieira and Carla Ferreira de Paula Gebara.

Contribution to manuscript preparation: Fernanda Monteiro de Castro Bhona, Carla Ferreira de Paula Gebara, Ana Regina Noto and Lélio Moura Lorenço.

Contribution to critical revision, adding intelectual content: Fernanda Monteiro de Castro Bhona, Carla Ferreira de Paula Gebara, Ana Regina Noto, Marcel de Toledo Vieira and Lélio Moura Lorenço.

\section{Conflicts of interest}

The authors declare that they have no conflict of interest related to the publication of this manuscript.

\section{References}

Abramsky, T., Watts, C. H., Garcia-Moreno, C., Devries, K., Kiss, L., Ellsberg, M., Jansen, H. A. F. M., \& Heise, L. (2011). What factors are associated with recent intimate partner violence? Findings from the WHO multi-country study on women's health and domestic violence. $B M C$
Public Health, 11(1), 109. doi: 10.1186/14712458-11-109

Antai, D. (2011). Controlling behavior, power relations within intimate relationships and intimate partner physical and sexual violence against women in Nigeria. BMC Public Health, 11(1), 511. doi: 10.1186/1471-2458-11-511

Archer, J. (2002). Sex differences in physically aggressive acts between heterosexual partners: A meta-analytic review. Aggression and Violent Behavior, 7, 313-351. doi: 10.1016/S13591789(01)00061-1

Brazilian Association of Market Research Companies. (2009). Brazilian Economic Classification Criterion. Retrieved from www.abep.org/Servi$\cos /$ Download.aspx?id=07

Brazilian Institute of Geography and Statistics. (2000). Demographic Census. Retrieved from https:// www.ibge.gov.br/en/np-statistics/multi-domain/ gender/18521-2000-population-census.html?edicao $=18537 \& \mathrm{t}=$ downloads

Capaldi, D. M., Knoble, N. B., Shortt, J. W., \& Kim, H. K. (2012). A systematic review of risk factors for intimate partner violence. Partner Abuse, 3(2), 231-280. doi: 10.1891/1946-6560.3.2.e4

Carvalho-Barreto, A., Bucher-Maluschke, J. S. N. F., Almeida, P. C., \& DeSouza, E. (2009). Desenvolvimento humano e violência de gênero: Uma integração bioecológica. Psicologia: Reflexão e Crítica, 22(1), 86-92. http://dx.doi.org/10.1590/ S0102-79722009000100012

Colossi, P. M., Razera, J., Haack, K. R., \& Falcke, D. (2015). Violência conjugal: Prevalência e fatores associados. Contextos Clínicos, 8(1), 55-66. doi: $10.4013 /$ ctc. 2015.81 .06

D’Oliveira, A. F. P. L., Schraiber, L. B., França-Júnior, I., Ludermir, A. B., Portella, A. P., Diniz, C. S., Couto, M. T., \& Valença, O. (2009). Fatores associados à violência por parceiro íntimo em mulheres brasileiras. Revista Saúde Pública, 43(2), 299-310. doi: 10.1590/S003489102009005000013

Dossi, A. P., Saliba, O., Garbin, C. A. S., \& Garbin, A. J. I. (2008). Perfil epidemiológico da violência física intrafamiliar: Agressões denunciadas num município do Estado de São Paulo, Brasil, entre 2001 e 2005. Cadernos de Saúde Pública, 24(8), 1939-1952. https://dx.doi.org/10.1590/ S0102-311X2008000800022 
Ellsberg, M., \& Heise, L. (2005). Researching violence against women: A practical guide for researchers and activists. Washington, DC: World Health Organization. Retrieved from http:// www.who.int/reproductivehealth/publications/ violence/9241546476/en/

Emery, C. R. (2011). Disorder or deviant order? Re-theorizing domestic violence in terms of order, power and legitimacy: A typology. Aggression and Violent Behavior, (16), 525-540. doi: 10.1016/j.avb.2011.07.001

Garcia-Moreno, C., Jansen, H. A. F. M., Hellsberg, M., Heise, L., \& Watts, C. H. (2006). Prevalence of intimate partner violence: Findings from de WHO multi-country study on women's health and domestic violence. Lancet, 368(7), 1260-1269. Retrieved from http://www.who.int/ gender/violence/who_multicountry_study/media_corner/Prevalence_intimatepartner_WHOStudy.pdf

Gebara, C. F. P. (2014). Padrões de violência doméstica e uso de álcool entre mulheres de uma amostra comunitária domiciliar (Doctoral dissertation, Programa de Pós-graduação em Psicobiologia, Universidade Federal de São Paulo, SP, Brazil).

Gebara, C. F. P., Ferri, C. P., Lourenco, L. M., Vieira M. T., Bhona, F. M. C., \& Noto, A. R. (2015). Patterns of domestic violence and alcohol consumption among women and the effectiveness of a brief intervention in a household setting: A protocol study. BMC Womens Health, 15, 78. doi: 10.1186/s12905-015-0236-8

Jewkes, R. (2002). Intimate partner violence: Causes and prevention. Lancet, 359(9315), 1423-1429. doi: 10.1016/S0140-6736(02)08357-5

Jewkes, R., Flood, M., \& Lang, J. (2015). From work with men and boys changes of social norms and reduction of inequities in gender relations: A conceptual shift in prevention of violence against women and girls. The Lancet, 385(9977), 15801589. http://dx.doi.org/10.1016/S0140-6736

Johnson, M. P., Leone, J. M., \& Xu, Y. (2014). Intimate terrorism and situational couple violence in general surveys: Ex-spouses required. Violence against Women, 20(2), 186-207. doi: $10.1177 / 1077801214521324$

Krug, E. G., Dahlberg, L. L., Mercy, J. A., Zwi, A. B., \& Lozano, R. (Eds.). (2002). World report on violence and health. Geneva: World
Health Organization. doi: 10.1016/S01406736(02)11133-0

Lamoglia, C. V. A., \& Minayo, M. C. S. (2009). Violência conjugal, um problema social e de saúde pública: Estudo em uma delegacia do interior do Estado do Rio de Janeiro, Ciência \& Saúde Coletiva, 14(2), 595-604. Retrieved from http:// www.redalyc.org/articulo.oa?id=63013532028

Michau, L., Horn, J., Bank, A., Dutt, M., \& Zimmerman, C. (2015). Prevention of violence against women and girls: Lessons from practice. The Lancet, 385(9978), 1672-1684. doi: 10.1016/ S0140-6736(14)61797-9

Moraes, C. L., Hasselmann, M. H., \& Reichencheim, M. E. (2002). Adaptação transcultural do instrumento "Revised Conflict Tactic Scales (CTS2)", utilizado para identificar violência entre casais. Cadernos de Saúde Pública, 18(1), 163-176. http://dx.doi.org/10.1590/S0102$-311 \mathrm{X} 2002000100017$

Moraes, C. L., \& Reichencheim, M. E. (2002). Cross-cultural measurement equivalence of the Revised Conflict Tactic Scales (CTS2) Portuguese version used to identify violence with couples. Cadernos de Saúde Pública, 18(3), 783-796. http://dx.doi.org/10.1590/S0102$-311 \mathrm{X} 2002000300022$

Moore, T. M., Stuart, G. L., Meehan, J. C., Rhatigan, D. L., Hellmuth, J. C., \& Keen, S. M. (2008). Drug abuse and aggression between intimate partners: A meta-analytic review. Clinical Psychology Review, 28, 247-274. doi: 10.1016/j. cpr.2007.05.003

Morgan, K., Buller, A. M., Evans, M., Trevillion, K., Williamson, E., \& Malpass, A. (2016). The role of gender, sexuality, context upon help seeking for intimate partner violence: A synthesis of data across five studies. Aggression and Violent Behavior, 31, 136-146. Retrieved from https://doi. org/10.1016/j.avb.2016.09.001

Moura, L. B. A., Gandolfi, L., Vasconcelos, A. M. N., \& Pratesi, R. (2009). Violências contra mulheres por parceiro íntimo em área urbana economicamente vulnerável, Brasília, DF. Revista Saúde Pública, 43(6), 944-953. doi: 10.1590/S003489102009005000069

Oliveira, J. B., Lima, M. C. P., Simão, M. O., Cavariani, M. B., Tucci, A. M., \& Kerr-Corrêa, F. (2009). Violência entre parceiros íntimos e álcool: Prevalência e fatores associados. Revista 
Panamericana de Salud Pública, 26(6), 494501. Retrieved from https://www.scielosp.org/ pdf/rpsp/2009.v26n6/494-501

Reichencheim, M. E., Moraes, C. L., Szklo, A., Hasselmann, M. H., Souza, E. R., Lozana, J. A., \& Figueiredo, V. (2006). The magnitude of intimate partner violence in Brazil: Portraits from 15 capital cities and the Federal District. Cadernos de Saúde Pública, 22(2), 425-437. http://dx.doi. org/10.1590/S0102-311X2006000200020

Schraiber, L. B., Barros, C. R. S., Couto, M. T., Figueiredo, W. S., \& Albuquerque, F. P. (2012). Homens, masculinidade e violência: Estudo em serviços de atenção primária à saúde. Revista Brasileira de Epidemiologia, 15(4),790-803. doi: 10.1590/S1415-790X2012000400011

Schraiber, L. B., D’Oliveira, A. F. P. L., \& Couto, M. T. (2006). Violência e saúde: Estudos científicos recentes [Special issue]. Revista Saúde Pública, 40, 112-120. http://dx.doi.org/10.1590/S003489102006000400016

Schraiber, L. B., D’Oliveira, A. F. P. L., \& França-Júnior, I. (2008). Violência sexual por parceiro íntimo entre homens e mulheres no Brasil urbano, 2005. Revista Saúde Pública, 42(Suppl. 1), 127-137. http://dx.doi.org/10.1590/S003489102008000800015

Schraiber, L. B., D’Oliveira, A. F. P. L., França-Júnior, I., Diniz, C. S., Portella, A. P., Ludermir, A. B., Valença, O., \& Couto, M. T. (2007). Prevalência da violência contra a mulher por parceiro íntimo em regiões do Brasil. Revista Saúde Pública, 41(5), 797-807. http://dx.doi.org/10.1590/ S0034-89102007000500014

Straus, M. A. (1999). The controversy of domestic violence by women: A methodological, theoretical, and sociology of science analysis. In X. B. Arriaga \& S. Oskamp, Violence in intimate relationships (pp. 17-44). Thousand Oaks, CA: Sage.

Straus, M. A. (2011). Gender symmetry and mutuality in perpetration of clinical-level partner violence: Empirical evidence and implications for prevention and treatment. Aggression and Violent Behavior, 16, 279-288. doi: 10.1016/j. avb.2011.04.010

Straus, M. A., \& Gozjolko, K. L. (2014). "Intimate terrorism" and gender differences in injury of dating partners by male and female university students. Journal of Family Violence, 29, 51-65. doi: 10.1007/s10896-013-9560-7

Straus, M. A., Hamby, S. L., Boney-McCoy, S., \& Sugarman, D. B. (1996). The Revised Conflict Tactic Scales (CTS2): Development and preliminary psychometric data. Journal of Family Issues, 17(3), 283-316. doi: 10.1177/019251396017003001

Thompson, M. P., \& Kingree, J. B. (2006). The roles of victim and perpetrator alcohol use in intimate partner violence outcomes. Journal of Interpersonal Violence, 21(2), 163-177. doi: $10.1177 / 0886260505282283$

World Health Organization. (2010). Preventing intimate partner and sexual violence against women: Taking action and generating evidence. Retrieved from http:/www.who.int/violence_ injury_prevention/violence/activities/intimate/ en/

Zaleski, M., Pinsky, I., Laranjeira, R., Ramisetty-Mikler, S., \& Caetano, R. (2010a). Violência entre parceiros íntimos e consumo de álcool. Revista Saúde Pública, 44(1), 53-59. http://dx.doi. org/10.1590/S0034-89102010000100006

Zaleski, M., Pinsky, I, Laranjeira, R., RamisettyMikler, S., \& Caetano, R. (2010b). Intimate partner violence and contribution of drinking and sociodemographics: The Brazilian national alcohol survey. Journal of Interpersonal Violence, 25(40), 648-665. doi: $10.1177 / 0886260509334396$

Received: 23/08/2016

$1^{\text {st }}$ revision: 06//11/2017

$2^{\text {nd }}$ revision: $30 / 03 / 2018$

Accepted: 02/05/2018

(cc) BY 1 (C) The Author(s), 2018. Open Access. This article is distributed under the terms of the Creative Commons Attribution 4.0 International License (http://creativecommons.org/licenses/by/4.0/), which permits unrestricted use, distribution, and reproduction in any medium, provided you give appropriate credit to the original author(s) and the source, provide a link to the Creative Commons license, and indicate if changes were made. 